\title{
Continuous Care Units: a response to aging and dependency in Portugal
}

\author{
Unidades de Cuidados Continuados Integrados: \\ uma resposta ao envelhecimento e à dependência em Portugal
}

\author{
Maria Carolina Monteiro ${ }^{1 *}$, Osvaldo Santos ${ }^{2}, \mathbf{M}^{\mathrm{a}}$ Céu Costa ${ }^{2,3}$ \\ ${ }^{1}$ Instituto de Segurança Social IP, Lisboa Portugal \\ ${ }^{2}$ CBIOS - Research Center for Health Bioscience and Technologies, University Lusófona, Campo Grande, 376, 1169-075 \\ Lisboa, Portugal \\ ${ }^{3}$ LNEG, Estrada da Portela, Bairro do Zambujal-Alfragide, Apartado7586,Alfragide, 2610-999 Amadora \\ Email:m.carolina.silva@seg-social.pt \\ * Developed under the Master Program in Integrated Continuous Care, ECTS - U Lusófona, Lisboa \\ * Desenvolvido no âmbito do Programa de Mestrado em Cuidados Continuados Integrados, ECTS - U Lusófona, Lisboa
}

\begin{abstract}
:
The Portuguese population is undergoing an irreversible aging process and must deal with this demographic issue. Many influencing factors have been identified, including biological, psychological and social changes which have led to this new social stratification.

The increasing prevalence of chronic and debilitating illnesses as a direct result of human aging has increased the demand for answers on both a health and social level. Life expectancy at birth in Portugal is almost 81 years, one year above the OECD mean. Life expectancy for women is 84 years, compared to 78 years for men. The National Network for Continuous Care (REDE) was formed in response to this new issue. The implementation of Continuous Care Units (UCCI) provide an alternative to hospitalization for dependent people needing special care but who do not require the specific care of an acute unit. The UCCI present a model of multidisciplinary intervention that covers all aspects of a health, social and economic nature and, consists of multidisciplinary teams. Due to the characteristics of the elderly and / or their situation of dependency, the intervention from specialized professionals of UCCI must be carefully prepared. Focused training and team expertise are key factors of the REDE's success.
\end{abstract}

Keywords: aging, REDE, dependency, Continuous Care, expertise.

\begin{abstract}
Resumo:
A população portuguesa encontra-se num processo de envelhecimento, e tem de enfrentar esta nova realidade demográfica. Vários determinantes nomeadamente biológicos, psicológicos e sociais, foram já identificados. $\mathrm{O}$ aumento da prevalência de doenças crónicas e incapacitantes, como consequência directa do envelhecimento humano, tem aumentado a procura de respostas na área da saúde e ao nível social. A Rede Nacional de Cuidados Continuados Integrados (REDE) surge como resposta a esta nova problemática. Através da implementação de Unidades de Cuidados Continuados Integrados (UCCI), a REDE é uma alternativa aos internamentos nos hospitais de pessoas em situação de dependência e com necessidade de cuidados diferenciados mas sem necessidade de cuidados típicos de uma unidade de agudos. As UCCI apresentam um modelo de intervenção multidisciplinar que contempla as vertentes da saúde, social e económica dos utentes, composta por equipas multidisciplinares. Devido às especificidades da população idosa e/ou dependente, a intervenção especializada dos profissionais das UCCI, deve ser cuidadosamente preparada com base no treino e especialização, aspectos centrais do sucesso da REDE.
\end{abstract}

Palavras-chave: Envelhecimento, REDE, dependência, Cuidados Continuados, Formação especializada. 


\section{Demographic aging}

Since the second half of the last century, most industrialized countries or those in the process of industrialization live with the drama of the rapid aging of their populations ${ }^{[1]}$. The increasing population of the elderly in the total population at the expense of young people and / or of working age ${ }^{[2]}$, has been indicated as a factor responsible for demographic changes. Economic, social and even cultural factors ${ }^{[3]}$ have contributed to this process that includes biological and psychological aspects ${ }^{[4]}$. Human aging is not only associated with increased life expectancy but also with a reduced mortality rate of the young and middle-aged individuals ${ }^{[5]}$. Several factors have been indicated as responsible for the increase in average life expectancy, namely: scientific advances in health and greater awareness and investment in terms of health and social policies. In addition, people's individual behavior has changed, particularly in the adoption of strategies for prevention and health promotion ${ }^{[6]}$. Accordingly, the health gains achieved have resulted in a significant increase in survival ability and hence, an increase in life expectancy. Between 2000 and 2008, life expectancy for men increased by 2.7 years, reaching an average 75.7 years and in women an increase of 1.9 years that equates to an average of 82.2 years $^{[7]}$. In 2011 the average life expectancy increased, becoming 76.7 years for men and 82.6 years for women ${ }^{[23]}$.

With the changing population profile and increased longevity, there has been an increase in the prevalence of chronic and debilitating illnesses which has inevitably resulted in increased demand for answers, not only in the health sector but also in the social field ${ }^{[6]}$. The World Health Organization (WHO) predicts for 2020 an increase of $20 \%$ in average life expectancy and disability-free life expectancy at the age of $65^{[7]}$. However, the increasing proportion of patients who suffer loss of capacity, in addition to changes in the population profile targets, have also been the subject of concern among several countries.

When addressing the issue of aging or old age associated with dependence, we must take into account several areas (social, health, economical, etc.) as well as all aspects related to the individual on a biopsychossocial level. Several authors explain aging in a general way, referring to it as a process in which changes occur in a biological, psychological and social way. Squire referred to aging as a process that depends on physiological, social and psychological factors, in that they may be combined with each other and occur without their necessarily being related to the age factor ${ }^{[8]}$. According to Fontaine aging, "Is not a state but a process

\section{Envelhecimento demográfico}

Desde a segunda metade do século passado que a maioria dos países industrializados ou em vias de industrialização vivem com o drama do rápido envelhecimento das suas populações ${ }^{[1]}$. O aumento da população de idosos na população total, em detrimento da população jovem e/ou em idade activa ${ }^{[2]}$, tem sido indicado como factor responsável pelas alterações demográficas. Para tal, têm contribuído factores de ordem económica, social e até cultural ${ }^{[3]}$, sendo um processo várias implicações, nomeadamente em termos biológicos, psicológicos e sociais ${ }^{[4]}$. O envelhecimento humano está associado não só ao aumento da esperança média de vida mas também à redução da taxa de mortalidade dos indivíduos jovens e dos de meia-idade ${ }^{[5]}$. Vários factores têm sido indicados como responsáveis pelo aumento da esperança média de vida, nomeadamente: os progressos científicos na área da saúde, uma maior consciencialização e investimento ao nível das políticas sociais e de saúde, bem como uma mudança nos próprios comportamentos individuais, principalmente na adopção de estratégias de prevenção e promoção da saúde e no adiamento da parentalidade ${ }^{[6]}$. Nesse sentido, os ganhos em saúde alcançados proporcionaram um aumento significativo da capacidade de sobrevivência e, consequentemente, o aumento da esperança média de vida. Entre o ano de 2000 e o ano de 2008, a esperança de vida para os homens aumentou 2,7 anos, situando a média nos 75,7 anos e nas mulheres um aumento de 1,9 anos o que equivale a uma média de $82,2 \operatorname{anos}^{[7]}$. Em 2011 a média da esperança de vida aumentou, passando a ser de 76,7 anos para os homens, e 82,6 anos para as mulheres ${ }^{[23]}$.

Com a mudança do perfil populacional e o aumento de longevidade, tem-se verificado o aumento da prevalência de doenças crónicas e incapacitantes e que inevitavelmente resulta no aumento das necessidades e da procura de respostas não só na área da saúde como também ao nível social ${ }^{[6]}$. A Organização Mundial de Saúde (OMS) perspectiva para 2020 um aumento de $20 \%$ na esperança média de vida e na esperança de vida sem incapacidade aos $65 \operatorname{anos}^{[7]}$. No entanto, o aumento da percentagem de indivíduos com perda de capacidade e as alterações do perfil da população também têm sido alvos de preocupação por parte de vários países.

Quando se aborda a questão da velhice ou do envelhecimento associada à dependência, deve-se ter em conta várias áreas e os aspectos ao nível biopsicossocial relacionados com o indivíduo. Vários autores explicam o envelhecimento de forma generalista, referindo-o como um processo no qual ocorrem alterações/mudanças nos 
of progressive degradation and differential. It affects living beings and their natural end is the death of the organism" $[9]$ i.e. aging can be regarded as a progressive and natural biological process, that begins at birth and will be manifested through the decline and gradual reduction of the functional capabilities of the cells ${ }^{[10]}$. In abbreviated form, the concept of aging is defined as the final state achieved of human development of every healthy individual who has not suffered any accident ${ }^{[11]}$. Throughout history, aging and old age have changed socially and in how they are represented: old age as a respectable status in traditional societies has become to represent isolation and dependence in industrialized societies. The main feature of old age is usually physical decline which leads to social and psychological changes. It is a continuous process that inevitably influences the social context of the individual ${ }^{[8]}$. Currently the social image of old age is somewhat confused between biological aging and social aging ${ }^{[12]}$. However, there are other factors that should also be considered to influence social attitudes regarding the elderly. These include changes in physical appearance, reduced response times, the proximity of death and increased dependency on others. In this context Guiddens indicates that aging can cause psychological, social and economic problems and can lead to loneliness and disorientation because people have to restructure a large part of their daily activities $^{[13]}$.

Usually, dependency is associated with old age, and may arise as a natural consequence of aging or may be associated with deficiency situations, whether natural (genetic defects) or acquired ${ }^{[13]}$. Dependence can be a temporary or permanent condition due to reasons associated with lack or loss of autonomy. This can be caused by physical, mental and / or intellectual conditions where individuals need the help of others to perform basic daily activities ${ }^{[14]}$. In the elderly, dependency can take on various forms which arise from the interference of external factors to their disability such as economic weakness resulting from low income, social isolation, dependency and lack of family support networks and social support ${ }^{[15]}$.

Today's society values youth, physical appearance and vitality, which makes the elderly and / or those in a position of dependency less visible. The aging population puts pressure on society through the cost burden of old-age assistance and healthcare as well as economic constraints, the structural crisis of employment being the most obvious. As it is evolves society increasingly values "labor" and the time available for the family is shrinking, leading to a strong demand for social responses to the problem of old age and dependency ${ }^{[13]}$. aspectos biológicos, psicológicos e sociais, tal como refere Squire: o envelhecimento é um processo que depende de factores fisiológicos, sociais e psicológicos, em que estes podem combinar-se entre si e ocorrerem sem que haja, obrigatoriamente, relação com o factor idade ${ }^{[8]}$. Segundo Fontaine, "não é um estado, mas sim um processo de degradação progressiva e diferencial. Ele afecta os seres vivos e o seu termo natural é a morte do organismo" "[9]. Ou seja: o envelhecimento pode ser considerado como um processo biológico progressivo e natural que tem início no nascimento e se vai manifestando através do declínio e diminuição progressiva das capacidades funcionais e das células ${ }^{[10]}$. Numa forma abreviada, o conceito de envelhecimento, define-se como o estado final do desenvolvimento humano do individuo sadio, e que não sofreu qualquer acidente ${ }^{[11]}$. Ao longo da história, o envelhecimento e a velhice têm sofrido mutações sociais e representacionais: do estatuto respeitável nas sociedades tradicionais transformou-se em isolamento e dependência nas sociedades industrializadas. A velhice tem como característica principal o declínio, geralmente físico, que leva as alterações sociais e psicológicas, sendo um processo ininterrupto que influência inevitavelmente o contexto social do indiví$\mathrm{duo}^{[8]}$. Actualmente a velhice situa-se entre o envelhecimento biológico e o envelhecimento social ${ }^{[12]}$. No entanto, existem outros elementos que devem ser igualmente considerados por serem influenciadores de atitudes sociais relativamente aos idosos e à velhice, nomeadamente a perda de aparência física, a capacidade de reacção, a proximidade da morte, o aumento da dependência, entre outros. Nesse contexto, Guiddens indica que o envelhecimento pode gerar problemas psicológicos, sociais e económicos, podendo levar à solidão e desorientação, pelo facto de as pessoas terem de reestruturar grande parte das suas actividades quotidianas ${ }^{[13]}$.

Usualmente, a dependência encontra-se associada à velhice, podendo surgir como consequência natural do envelhecimento ou estar associada a situações de deficiência, seja esta natural (malformações congénitas) ou adquiri$\mathrm{da}^{[13]}$. A dependência pode ser um estado provisório ou definitivo que, por razões associadas à falta ou perda de autonomia, seja esta de origem física, psíquica ou/e intelectual, em que os indivíduos necessitam da ajuda de terceiros para realizar as actividades básicas quotidianas ${ }^{[14]}$. Nas pessoas idosas, a dependência pode assumir diversas formas, resultante da interferência de factores externos à sua incapacidade física, tais como (entre outros): fragilidade económica resultante de baixos rendimentos, isolamento social, dependência de familiares, escassez de redes de suporte e apoio social, etc. ${ }^{[15]}$.

A sociedade actual valoriza a juventude, a aparência 
Changes in the structure of society have revealed the inadequacy in health and social responses in our country regarding this new reality, and the low value of the benefits and deficiencies in the health system, where the examples are evident ${ }^{[16]}$. These changes have been equally felt by countries outside the European Union, which for several years has been developing strategies to meet the growing care needs. The European Union has shown a growing interest in health and social care. This has prompted new priorities which are aimed at ensuring access to existing services and adapting them to the changes, which include socio-demographic changes ${ }^{[17]}$.

Currently, the average life expectancy is around 82 years but the WHO predicts for 2020 an increase of $20 \%$ in average life expectancy and disability-free life expectancy at the age of 65 . Associated with this increase is the rise in chronic diseases that in the last decade alone have increased by $21 \%$.

On $31 / 12 / 2011$ the total number of individuals older than 65 years was 320961 , representing 20,3\% of the population residing in the mainland. Given the contingency of increase among elderly residents to $31,9 \%$ in 2050, it is envisaged that Portugal is one of the EU countries with the highest percentage of elderly people $^{[18]}$.

\section{Portugal, an aging country}

Like most industrialized countries, the Portuguese population is progressively aging. Despite showing a lower percentage compared to some European countries, in recent decades there has been a significant increase in the percentage of elderly people, especially among the female population ${ }^{[12]}$. In Portugal, men and women aged over 65 years are considered elderly ${ }^{[23]}$. This age is associated with the retirement age, being the reference point indicative of the end of mandatory professional activity. Studies have shown that in 1993 for every 100 young people under the age of fifteen there were about 79 people over 65 years of age ${ }^{[19]}$. Already in 2000, for every 100 young people aged less than 15 years, there were 102 elderly people and in 2004 this figure was 110 per 100 young people ${ }^{[20]}$. Therefore, between 1993 and 2004 and with reference to the number of children under fifteen years of age física e a vitalidade, o que vai tornando invisíveis as pessoas idosas e/ou dependentes pelo que existe uma pressão relacionada com o envelhecimento da população (com o respectivo encargo nas despesas de assistência na velhice e na saúde) e os condicionalismos económicos (por exemplo: a crise económica, em que a crise estrutural do emprego é a mais evidente). À medida que evolui, a sociedade torna-se cada vez mais "trabalhista", em que o tempo disponível para a família é cada vez menor, levando a uma acentuada procura de respostas sociais para o problema da velhice e da dependência ${ }^{[13]}$. As mudanças na estrutura da sociedade vieram revelar a desadequação nas respostas sociais e de saúde no nosso país relativamente à nova realidade, sendo o baixo valor das prestações sociais e as deficiências no sistema de saúde, dos exemplos mais evidentes ${ }^{[16]}$. Mudança essas que têm sido igualmente sentidas por países não pertencentes à União Europeia, que desde há vários anos vêm desenvolvendo estratégias para responder às crescentes necessidades de cuidados. A União Europeia tem demonstrado um crescente interesse pelos cuidados de saúde e sociais, o que promoveu a definição de novas prioridades, visando a garantia do acesso a serviços existentes e a adequação dos mesmos às mudanças, nomeadamente às sociodemográficas ${ }^{[17]}$

No último dia de 2011, o total de indivíduos com mais de 65 anos era de 320.961, representando 20,3\% da população residente em território continental. Perante a contingência de aumento da população idosa residente para $31,9 \%$, em 2050, perspectiva-se que Portugal seja um dos países da União Europeia com maior percentagem de idosos ${ }^{[18]}$.

\section{Portugal, um país em envelhecimento}

Tal como na maioria dos países industrializados, a população portuguesa encontra-se num processo de envelhecimento progressivo e, aparentemente, irreversível. Apesar de apresentar uma percentagem mais baixa em relação a alguns países europeus, registou-se nas últimas décadas um aumento significativo da percentagem de pessoas idosas, especialmente entre a população feminina $^{[12]}$. Em Portugal, são consideradas pessoas idosas os homens e as mulheres com idade igual ou superior a 65 anos $^{[23]}$. Esta idade está associada à idade da reforma, sendo o ponto de referência indicativo do fim da obrigatoriedade do exercício de actividade profissional.

Estudos realizados demonstraram que no ano de 1993 por cada 100 jovens com idade inferior a quinze anos havia cerca de 79 indivíduos com mais de 65 anos de ida-

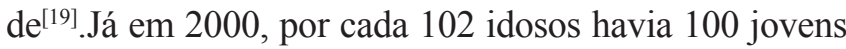
com idade inferior a 15 anos, sendo que em 2004 esse valor era de 110 idosos por cada 100 jovens ${ }^{[20]}$. Ou seja: 
there was an increase of about $13,9 \%$ in the elderly population. Between 2001 and 2009, considering the resident population in Portugal, the percentage of the elderly population in Portugal increased from 16,5\% to $17,9 \%$. It is envisaged that this trend will continue and it is estimated that in 2050 Portugal will be one of the EU countries with the highest percentage of elderly people, experiencing an increase from $16,9 \%$ in 2001 to $31,9 \%$ in $2050^{[21]}$.

Taking into account developments in the last three decades (between 1981 and 2010), in which the elderly population increased from 1.125 million to 1.881 million, it would appear that the elderly population will reach 2.14 million in 2020 . This increase represents $20,4 \%$ of the total population and corresponds to a $87 \%$ increase over the past four decades ${ }^{[22]}$.

Inevitably there was a rise in chronic diseases associated with this increase. The total dependency ratio rose from 48 in 2001 to 52 in 2011, i.e. for every 100 people of working age there are 52 who are dependent ${ }^{[23]}$. This increase in the rate of deterioration of total dependence is due to a higher elderly dependency ratio, which according to the second report of the 2011 Census, has increased by $21 \%$ in the last decade alone ${ }^{[23]}$. As regards dependency associated with old age, the National Health Plan (NHP) 20112016 estimates that in 2016 in Portugal, more than 5.2 million people will be suffering from at least one chronic disease and 2.6 million will be suffering from two or more chronic diseases. It is possible that about $3 \%$ of the population will be suffering from five or more chronic diseases. Similarly, it is estimated that in 2020, 10 in every 100 people will be dependent in carrying out the activities of daily living (ADL) ${ }^{[24]}$.

In Portugal, as in other industrialized countries, demographic changes have caused the structure and dynamics of families to change. This has led to the need for social support resources that replace family responsibilities in order to support the care and monitoring of the elderly.

This change in family structure, where extended families have become nuclear, has meant that there is no longer room for the elderly. Increasingly, the elderly live alone and when they do not have the physical and / or psychological capacity they live in residences or homes, which play the role of the family ${ }^{[16]}$.

However, the increase in the percentage of individuals who suffer a loss of capacity is changing the profile of the population and has become the object of concern of the governing bodies. This has led to the search for new solutions that respond to this problem in its various aspects: health, social and economic.

Indeed, until now, hospitals were the only answer / entre 1993 e 2004 e tendo como referência o número de jovens com menos de quinze anos de idade houve um aumento de cerca de 13,9 \% da população idosa. Entre 2001 e 2009, e considerando a população residente em Portugal, a percentagem da população idosa em Portugal aumentou de $16,5 \%$ para $17,9 \%$. Nesse sentido perspectiva-se que esta tendência manter-se-á, estimando-se que Portugal seja, em 2050, um dos países da União Europeia com maior percentagem de idosos, passando de $16,9 \%$, no ano de 2001 , para $31,9 \%$ no ano de $2050^{[21]}$. Tendo em conta a evolução registada nas últimas três décadas (entre 1981 e 2010), em que a população idosa passou de 1,125 milhões para 1,881 milhões, tudo aponta para que o númeno de idosos atingirá os 2,14 milhões em 2020. Este aumento representará 20,4 \% da população total e correspondendo a um aumento de 87 $\%$ nas últimas quatro décadas ${ }^{[22]}$.

Associado a este aumento da população mais idosa, assiste-se ao aumento das doenças crónicas. $\mathrm{O}$ índice de dependência total subiu de 48, em 2001, para 52 em 2011, ou seja: por cada 100 pessoas em idade activa existem 52 dependentes ${ }^{[23]}$. Este aumento do agravamento do índice de dependência total é resultante do aumento do índice de dependência de idosos, que segundo relatório dos Censos 2011,só na última década aumentou 21\% ${ }^{[23]}$. No que se refere à dependência associada à velhice, o Plano Nacional de Saúde (PNS) 2011-2016 estima que em 2016, em Portugal mais de 5,2 milhões de pessoas deverão ser afectadas com pelo menos uma doença crónica e 2,6 milhões a sofrer de duas ou mais doenças crónicas, podendo mesmo haver cerca de $3 \%$ da população que sofra de cinco ou mais doenças crónicas De igual modo estima que em 2020,10\% dos portugueses estará dependente para a realização das actividades da vida diária (AVD) de forma autónoma ${ }^{[24]}$.

Em Portugal, tal como em outros países industrializados, a estrutura e dinâmica das famílias modificou-se devido às alterações demográficas já descritas, conduzindo à necessidade de criar recursos sociais de apoio que substituíssem as responsabilidades familiares e apoiassem no cuidado e acompanhamento dos idosos. Esta alteração na estrutura familiar, em que as famílias alargadas deram lugar a famílias nucleares, levou a que já não houvesse espaço para os idosos. Cada vez mais, os idosos vivem sozinhos e quando já não têm condições físicas e/ou psíquicas para tal, são integrados em lares ou residências que, por sua vez, desempenham o papel de apoio, tradicionalmente assumido pela família ${ }^{[16]}$.

Assim, o aumento da percentagem de indivíduos com perda de capacidade e, consequentemente, as alterações do perfil da população passaram a ser alvo de preocupação por parte das entidades governantes, levando à procura de novas soluções que viessem responder a esta problemática nas suas várias vertentes: saúde, social e económica. 
alternative for people who were in a situation of dependency and needed special care, even when they did not need the care of a typical acute unit. These events promoted excessive stays in hospital, causing a negative impact economically and on efficiency and responsiveness to acute situations.. Patients themselves are exposed to sources of infection and other adverse elements affecting recovery. Therefore, urgent and appropriate ways of responding to persons in situations of dependency during the various stages of disease / recovery are needed. These responses should facilitate the autonomy and participation of the target group in order to strengthen their capacities and skills, as well as to support their families. This is the aim of a new form of intermediate care (between hospital and community network), which applies a model that evaluates and treats the individual holistically through intersectorial co-operation on a health, social and family level ${ }^{[25]}$.In this context, Ferreira argues that continuity of care should be seen as the main element in the process of care. Care should be such that not only the continuity and differentiated factors are considered, but that it goes beyond the immediate care given in acute situations and in the hospital, and looks at the social aspect ${ }^{[6]}$.However, Dias argues that this type of care is understood as a response, rather than a resource to minimize the results arising from the fragmentation and discontinuity of care, one of the characteristics of social systems and healthcare in Europe ${ }^{[17]}$.

Social policies are implicitly concerned with the social element in the political dimension and include the public welfare. This means meeting the public's needs and taking into account the interference of non-social policies. This distinction between the various policy aims ensures that they are applied in accordance with their genesis. In fact, social policies emerge as the state's response to social needs that arise in accordance with the guarantee of Citizenship Rights, This is done through the provision of access to goods and services in certain fundamental areas of human welfare (health, education, housing, etc.) ${ }^{[26]}$. Social responses are presented as a set of key measures of an economic and social nature, emanating from a political strategy aimed at promoting equitable development of societies. These responses are mainly aimed at ensuring access to fundamental rights (education, health and social) for the most vulnerable in society as set out in the law. This promotes better quality of life and reduces inequalities that can result in insecurity and social instability ${ }^{[27]}$.

The emergence of new active policies has assisted in
Até recentemente, as unidades hospitalares constituíam a única resposta/alternativa para as pessoas que se encontravam em situação de dependência e com necessidade de cuidados diferenciados, mesmo quando já não necessitassem de cuidados típicos de uma unidade de agudos. Estas ocorrências promoviam permanências excessivas nas unidades hospitalares, causando um impacto negativo não só ao nível da eficiência e capacidade de resposta a situações agudas, como em termos económicos e para os próprios utilizadores, uma vez que permaneciam expostos a focos de infecção e outros elementos adversos à sua recuperação. Perante esta evidência, era urgente a criação e promoção de respostas adequadas para pessoas em situação de dependência, durante os vários estágios da doença/recuperação. Respostas essas facilitadoras da autonomia e da participação dos visados, reforçando as suas capacidades e competências, bem como das suas famílias, com uma nova forma de cuidados intermédios (entre a rede hospitalar e a comunidade), com a aplicação de um modelo intersectorial que avalia e trata o individuo de uma forma holística, intervindo ao nível da saúde, ao nível social e familiar ${ }^{[25]}$. Nesse contexto, Ferreira defende que a continuidade dos cuidados deve ser encarada como o elemento principal no processo de prestação de cuidados. Cuidados estes que devem ser não só de continuidade e diferenciados, mas irem além dos cuidados imediatos prestados nas situações agudas e no contexto hospitalar, contemplando inevitavelmente a vertente social ${ }^{[6]}$. No entanto, Dias defende que este tipo de cuidados é entendido como uma resposta, mais do que um recurso, para minimizar os resultados decorrentes da fragmentação e da descontinuidade da prestação de cuidados, uma das características dos sistemas sociais e de saúde na Europa ${ }^{[17]}$.

O campo das políticas sociais tem implícita a identificação do elemento social na dimensão política e contempla o bem-estar público, na satisfação das suas necessidades, contando também com a interferência das políticas consideradas não sociais. Esta articulação entre as várias politicais tem como objectivo viabilizar a sua aplicação de acordo com a sua génese.

As políticas sociais surgem como resposta do Estado para responder às necessidades sociais que surgem, numa efectivação de garantia dos Direitos de Cidadania, através do acesso à prestação de bens e serviços em áreas fundamentais ao bem-estar humano e social (saúde, educação, habitação, entre outras $)^{[26]}$. As respostas sociais apresentam-se como um conjunto de medidas fundamentais, de natureza económica e social, emanadas de uma estratégia política que visa promover o desenvolvimento equitativo das sociedades. Visam, essencialmente, a garantia do acesso das camadas mais vulneráveis da sociedade aos direitos fundamentais 
this paradigm shift. These focus on continuity of care and favor the development of differentiated and specialized care, allowing for patients to be discharged from hospital when only rehabilitation and continued treatment is required ${ }^{[28]}$. Indeed, at the beginning of the 70s, new policies and social responses appeared in order to respond to aging and dependence through comprehensive and integrated intervention. These were the result of the relationship of shared responsibility between the state and the family. This inspired a new model which provided a combination of resources and facilities, a collaboration of state, family even private initiatives ${ }^{[29]}$. This model arose in the $70 \mathrm{~s}$, following the extension of social protection rights for workers, including access to benefits for those of retirement age or for those unfit to work. It became a problem due to the financial demands to which the State was subject. . The problem was overcome in the 80 s through a transfer of responsibilities, with the creation of private not-for-profit institutions (IPSS)..These intervene in health, education, housing, and in the provision of equipment for the elderly ${ }^{[12]}$. Given the new situation, the welfare state inevitably had to rethink its approach to aging and dependency and create new answers to replace functions that were previously undertaken by families. The changing population characteristics and the evolution of society means that there is less time and capacity to dedicate to these functions, which include the care of the elderly and the dependent. However, as Correia mentioned, Portugal remains one of the countries with the least social support structures and above all, less health care for dependents and the elderly ${ }^{[30]}$.

The new demographic structure and the urgent need to create specific and comprehensive responses in the areas of old age and dependent people, which involve the provision of hospital care and take the social aspect into consideration, were and are decisive factors in the genesis of Integrated Continuous Care in Portugal. (educação, saúde e assistência social) consignados na lei, permitindo a promoção de uma melhor qualidade de vida, atenuando as desigualdades promotoras de insegurança e de instabilidade social ${ }^{[27]}$.

O surgimento de novas políticas activas tem coadjuvado nesta mudança de paradigma, apostando nos cuidados de continuidade, favorecendo o desenvolvimento de cuidados especializados e diferenciados, possibilitando as altas hospitalares de situações que apenas necessitam de reabilitação e tratamento continuado ${ }^{[28]}$. Efectivamente, no início da década de 70 surgiram novas políticas e respostas sociais, com o objectivo de responder à problemática do envelhecimento e da dependência, ou em simultaneamente em caso de necessidade, através de uma intervenção ampla e integrada. Decorrentes da relação de partilha de responsabilidades entre o Estado e a família, deu origem a um novo modelo que previa uma combinação dos recursos e dos meios utilizáveis pelo Estado, dos recursos familiares e também junto do mercado ou, ainda, das iniciativas privadas ${ }^{[29]}$. Este modelo, que surge na sequência do alargamento dos direitos de protecção social aos trabalhadores, principalmente no acesso de todos a pensões por limite de idade ou por incapacidade para o trabalho, tornou-se num problema devido ao esforço financeiro a que o Estado ficou sujeito. A situação foi ultrapassada nos anos 80 através de uma transferência de responsabilidades, com a criação de instituições de carácter particular mas sem fins lucrativos (IPSS - Instituições Privadas Sem fins Lucrativos) e que, além da criação de equipamentos para apoio à terceira idade, passaram a intervir na área da saúde, da educação, da habitação e a criação de equipamentos para apoio à terceira idade ${ }^{[12]}$.

Perante a nova conjuntura, o Estado Providência teve inevitavelmente de repensar a abordagem à problemática do envelhecimento e da dependência e criar novas respostas para substituir funções que anteriormente eram cometidas pelas famílias. A mudança das características populacionais e a evolução da sociedade, que deixou menos tempo e menos capacidade para desenvolver essas funções, nomeadamente do cuidar dos idosos cada vez mais idosos e dependentes. No entanto, tal como Correia refere, Portugal continua a ser um dos países menos dotados de estruturas de apoio social e, sobretudo, de cuidados de saúde a pessoas dependentes e idosas ${ }^{[30]}$.

A nova estrutura demográfica e a urgência da criação de respostas específicas e abrangentes tanto na área da velhice como na área da dependência, que contemplassem a prestação de cuidados de saúde diferenciados e contemplassem a vertente social, foram factores decisivos e estão na génese dos Cuidado Continuados Integrados em Portugal. 


\section{Integrated Continuous Care (CCI)}

Continuous Care (CC) arose in Portugal after the establishment in 2005 of a working group called Mission Unit for Continuing Care (UMCCI). This aimed to develop strategies that could provide appropriate solutions to the current needs of the elderly and / or those in a situation of dependence or loss of autonomy Social and health policies, based on an integrated model, aim to create conditions in which people can live with satisfactory health by using existing resources in a complementary partnership between the social sector, and private health sector. The National Network of Integrated Continuous Care (RNCCI), designated REDE and legislated by Decree-Law N ${ }^{\circ}$. 101/2006 of 6 June $^{[31]}$, was created in this framework. The REDE was designed to respond to situations where the elderly and / or those in situations of dependency do not require admission to hospital but do need effective and appropriate continuing care, regardless of age ${ }^{[32]}$. REDE's mission is to therefore to provide continuity of care and social support.

With the creation of RNCCI, the concept of "integrated care" is emerging as a new paradigm, with the capacity to provide solutions to many problems created by dividing the areas of health and social services ${ }^{[17]}$. According to Ferreira and taking into account the definition issued by the RNCCI, Integrated Continuous Care (CCI) are defined as a set of integrated interventions in health and social care. The care provided is based on a joint assessment and seeks the recovery of the whole person. In this case the person is seen as the centre of a process of continuous therapeutic and social support.. The CCI aim to promote independence and improve the functionality of the person in a situation of dependency, through their rehabilitation and reintegration into the family and social context ${ }^{6]}$.

This social and healthcare response safeguards chronic or acute situations of dependency and / or disability, which may arise at any time during an individual's life. As such, they provide access to care and support for all individuals who are unable to carry out the activities of daily life and where there is an absence or lack of family support [31]. This lack or loss of autonomy, whether physical or mental,.may be a result of or aggravated by: chronic illness, organic dementia, post-traumatic consequences, disability, severe illness and / or incurable advanced stage illness.. Therefore, access is not exclusive to older people, but rather available to all individuals who are in the situation described.

The REDE operates under the aegis of the Ministry of Health and the Ministry of Labour and Social Solidarity

\section{Os Cuidados Continuados Integrados (UCCI)}

Os Cuidados Continuados surgiram em Portugal após ter sido foi constituído em 2005 um grupo de trabalho designado por Unidade de Missão para os Cuidados Continuados, que teve por objectivo o desenvolvimento de estratégias que viessem a ser soluções adequadas às necessidades actuais da população idosa e/ou em situação de dependência ou de perda de autonomia, pressupondo a criação de condições para que as pessoas possam viver com saúde, tendo por suporte a operacionalização de políticas de saúde e sociais, assentes num modelo Integrado, em que se pretende a potencialização dos recursos existentes, numa complementaridade entre o sector social, privado e da saúde. Neste enquadramento, foi criada a Rede Nacional de Cuidados Continuados Integrados (RNCCI), designada REDE, legislada pelo Decreto-Lei $n^{\circ} 101 / 2006$, de 6 de Junho ${ }^{[31]}$.

A REDE foi projectada para responder a situações de pessoas idosas e /ou em situação de dependências, que não necessitam de internamento em hospital de agudos mas com necessidade de cuidados continuados, de forma eficaz e adequada, independentemente da idade dos indivíduos ${ }^{[32]}$. Com base na implementação de novos serviços de promoção de continuidade de cuidados de saúde e de apoio social. Tem por missão a prestação de cuidados de saúde e de apoio social

Com a criação da RNCCI, o conceito de "cuidado integrado" surge como um novo paradigma, potenciando soluções para diversos problemas criados pela divisão entre as áreas da saúde e dos serviços sociais ${ }^{[17]}$. Segundo Ferreira, e tendo em conta a definição emanada da Rede Nacional de Cuidados Continuados Integrados, os Cuidados Continuados Integrados (CCI) são definidos como um conjunto de intervenções integradas de saúde e apoio social, baseadas numa avaliação conjunta e visam a recuperação total da pessoa. Neste processo, a pessoa é entendida como o centro de um processo terapêutico e de apoio social, activo e contínuo. Os CCI têm por objectivo promover a autonomia e a melhoria da funcionalidade da pessoa em situação de dependência, através da sua reabilitação, readaptação e da reinserção familiar e social." "[6].

$\mathrm{Na}$ concepção desta resposta social e de saúde, foram salvaguardadas as situações crónicas ou agudas de dependência e/ou deficiência, que podem surgir em qualquer momento da vida dos indivíduos. Como tal, têm acesso à REDE todos os indivíduos que por ausência ou perda de autonomia psíquica ou intelectual, por falta de autonomia física, psíquica ou intelectual, resultante ou agravada por doença crónica, demência orgânica, sequelas pós-traumáticas, deficiência, doença severa e/ou incurável em fase avançada, por ausência ou insuficiência 
(MTSS), in partnership with an undetermined number of care providers. These can be public or private institutions which under State protocols, provide a continuum of care in the home of the beneficiary or in the institution's own facilities. REDE is organized into units and teams of continued health and social care. The teams are multidisciplinary and consist of doctors, nurses, physiotherapists, social workers, and other professionals and carers who provide palliative care ${ }^{[31]}$.

Continuous Care Units (UCCI) present an effective response to the problem under discussion. They ensure continuity of care beyond the immediate care provided in acute situations in the hospital context. As Netto comments, the UCCI is a response that functions through flexible actions and that requires special equipment and techniques. Its primary objective is the restoration of health and it seeks to restore balance and capabilities so that individuals can return to their homes where possible ${ }^{[32]}$.

With regards to the social aspect, it is an effective response-oriented promotion of continuous and personalized care where the patient is empowered ${ }^{17]}$.Its main objective is the overall recovery of the individual, which involves a therapeutic and social process ${ }^{[33]}$. The UCCI intervene at various stages of disease, hence the need for diversified responses that are consistent with the specific situations of each patient. In inpatient units, the field of action / intervention is defined according to the needs of the healthcare user. The UCCI inpatient units are divided into four distinct types, and when necessary these can form a complementarity programme for continuation of care:

- Convalescence Units (CV) are independent inpatient units, integrated in acute hospitals or other institutions that are in direct connection with an acute hospital. They provide continuous, intensive treatment, clinical supervision, clinical care and rehabilitation to people following their hospitalization due to an acute clinical situation, a recurrence or decompensation of a chronic process. Their purpose is to stabilize the clinical and functional assessment and rehabilitation of the person who is suffering from potentially recoverable transient loss of autonomy, but who does not require hospital acute care. These units are designed to deal de apoio familiar ou de outra natureza, é incapaz de realizar as suas actividades da vida diária ${ }^{[31]}$. Ou seja, o acesso não é exclusivo a pessoas idosas, mas sim para todos os indivíduos que se encontrem em situação descrita.

A REDE é tutelada pelo Ministério da Saúde e pelo Ministério do Trabalho e Solidariedade Social (MTSS), em parceria com prestadores de cuidados, que podem ser instituições, públicas ou privadas que, ao abrigo de protocolos celebrados com o Estado, prestam cuidados continuados, tanto no local de residência do utente, como em instalações próprias. A REDE está organizada por unidades e equipas de cuidados continuados da área da saúde e social, com equipas multidisciplinares, constituídas por médicos, enfermeiros, fisioterapeutas, assistentes sociais, e outros profissionais que prestam cuidados e acções paliativas ${ }^{[31]}$.

\section{As Unidades de Cuidados Continuados Integrados}

(UCCI) apresentam-se como uma resposta efectiva à problemática do envelhecimento dependente e da dependência, assegurando cuidados de saúde de continuidade e diferenciados, para além dos cuidados imediatos prestados nas situações agudas em contexto hospitalar. Tal como Netto (2002) refere, as UCCI constituem uma resposta que se efectiva através de acções flexíveis, que carecem de técnicos e equipamentos específicos e que têm como objectivo principal o restabelecimento das situações de saúde, procurando o equilíbrio e a manutenção das capacidades de modo a que os indivíduos, sempre que possível, possam retornar aos seus lares ${ }^{[32]}$.

No que se refere à vertente social, é uma resposta efectiva e orientada para a promoção da continuidade e personalização na prestação de cuidados e na promoção da autonomia dos utentes ${ }^{[17]}$. Tem como objectivo principal a recuperação global do indivíduo, entendido como um processo terapêutico e social uno ${ }^{[33]}$. As UCCI intervêm em vários estádios de doença daí a necessidade de ter respostas diversificadas que se coadunem com as situações específicas de cada utente. Nas unidades de internamento, o campo de actuação/intervenção é definido de acordo com as necessidades dos utentes em termos de estado de saúde. As UCCI, enquanto unidades de internamento, dividem-se em quatro tipologias distintas, que quando necessário, se podem articular num regime de complementaridade, para continuação da prestação de cuidados:

- As Unidades de Convalescença (CV) são unidades de internamento independentes, integradas em hospitais de agudos ou noutras instituições, em directa articulação com um hospital de agudos. Prestam tratamento e supervisão clínica, de forma continuada e intensiva, e cuidados clínicos de reabilitação, na sequência de internamento hospitalar originado por uma situação clínica aguda, uma recorrência, ou uma descompensação de um processo crónico. Têm por finalidade a estabilização clínica 
with admissions of up to 30 consecutive days, and can coexist with inpatient medium-term and rehabilitation units. Their clients are mostly dependent patients who require intensive rehabilitation (Art. 13 and 14) ${ }^{[34]}$.

- The Medium Term and Rehabilitation (UMDR) inpatient units have their own specific location linked to acute hospitals. They provide clinical care, rehabilitation and psychosocial support to people with potentially recoverable transient loss of autonomy. They aim for clinical stabilization, assessment and rehabilitation of the whole person. Admission periods are normally longer than 30 days and less than 90 days (Art. 15 and 16$)^{[35]}$. Patients who are admitted to these units come from other areas of the Network, health institutions or home care providers, if they need integrated but not technologically differentiated care..

- Long Term and Maintenance Units (ULDM) are inpatient units with their own specific location., They provide social support and health care services to people with chronic diseases or who are at different levels of dependency and who do not meet conditions to remain and / or be cared for at home. They aim to provide specific care to prevent and slow down the increasing level of dependency, and prioritise comfort and quality of life. The period of stay is more than 90 consecutive days. These units aim to respond to social and health needs, to maximize the retention of skills for daily living activities, to facilitate the management of high acute hospitals and to promote the autonomy and satisfaction of the patient. Most of the users are admitted in these units due to their situation of dependency, for reasons of illness or age-related pathologies which require continued care. This may also be provided by other units in the network such as different types of health or welfare institutions and social security or home care (Art. 17 and 18) ${ }^{[36]}$.

- The Palliative Care Units (CP) are inpatient units normally located in hospitals. They provide support, treatment and clinical supervision. The majority of patients in these integrated units have a complex clinical condition resulting from severe disease and / or an advanced, progressive and incurable illness. There is no pre-defined admission period for these units due to the complexity of the patient's clinical condition (Art. 19 and 20$)^{[37]}$.

In order to provide support and respond to situations that require ongoing care but which do not require hospitalization, specific units were created that operate beyond the context of UCCI and hospital units.

- Outpatient Units, designated Day and Autonomy Promotion Units (UDPA) provide integrated care support, promote autonomy and provide social support to people whose condition does not require home care e funcional, a avaliação e reabilitação integral da pessoa com perda transitória de autonomia, potencialmente recuperável, e que não necessita de cuidados do hospital de agudos. Estas unidades destinam-se a internamentos com previsibilidade até 30 dias consecutivos, sendo que, podem coexistir com unidades de internamento de média duração e reabilitação. Os seus utentes são maioritariamente doentes dependentes e a necessitar de reabilitação intensiva (Art. ${ }^{\circ} 13^{\circ}$ e $\left.14^{\circ}\right)^{[34]}$.

- As Unidade de Média Duração e Reabilitação (UMDR) são unidades de internamento localizadas em espaço físico próprio, articuladas com os hospitais de agudos, e prestam cuidados clínicos de reabilitação e apoio psicossocial, a pessoas com perda transitória de autonomia potencialmente recuperável devido a situação clínica decorrente de recuperação de um processo agudo, ou descompensação de processo patológico crónico. Têm por finalidade a estabilização clínica, a avaliação e a reabilitação integral da pessoa. Os internamentos têm um período previsível superior a 30 dias e inferior a 90 dias (Art. ${ }^{\mathrm{o}} 15^{\circ}$ e $\left.16^{\circ}\right)^{[35]}$. Os doentes que são admitidos nestas unidades provêm de outras respostas da Rede, de instituições de saúde ou de solidariedade e segurança social ou do domicílio, caso necessitem de cuidados integrados em regime de internamento, mas não de cuidados tecnologicamente diferenciados.

- As Unidades de Longa Duração e Manutenção (ULDM) são unidades de internamento, situadas em espaço físico próprio, que prestam apoio social e cuidados de saúde de manutenção a pessoas com doenças ou processos cróni$\cos$, com diferentes níveis de dependência e que não reúnam condições para permanecerem e/ou serem cuidadas no domicílio. Têm por finalidade proporcionar cuidados específicos que previnam e retardem o agravamento das situações de dependência, privilegiando o conforto e a qualidade de vida. O período de internamento é superior a 90 dias consecutivos. Estas unidades pretendem responder a necessidades sociais e de saúde, maximizando a manutenção de aptidões para actividades de vida diária, facilitar a gestão das altas dos hospitais de agudos e promover a autonomia e a satisfação de necessidades sociais dos doentes. Na sua maioria, os utentes são admitidos nestas unidades pela sua situação de dependência, por razões de doença ou de patologias associadas à idade necessitam de cuidados continuados integrados e podem vir de outras respostas da Rede, nomeadamente de outras unidades de diferente tipologia, de instituições de saúde ou de solidariedade e segurança social ou do domicílio (Art. ${ }^{\circ} 17^{\circ}$ e $\left.18^{\circ}\right)^{[36]}$.

- As Unidades de Cuidados Paliativos (UCP) são unidades de internamento, com espaço físico próprio, preferencialmente localizadas em hospitais, de modo a proporcionarem acompanhamento, tratamento e supervisão clínica. Na sua maioria, os doentes integrados nesta unidades têm uma situação clínica complexa, e de sofrimento, decorrentes de doença severa e/ou avançada, incurável e pro- 
(Art. 21.). These units provide care in order to promote the patient's independence, to help them remain active and to provide support in the areas of healthcare, nursing, physiotherapy, psychosocial, entertainment, food and personal hygiene ${ }^{[38]}$.

- Home Care Units consist of two distinct teams: The Integrated Continuous Care Team (ECCI), formed of multidisciplinary teams which are responsible for primary health care, and the social support team which provides home services to people who are functionally dependent due to terminal illness or who are in the process of recovery. These patients do not require hospitalization but are unable to leave their residence (Art. 27). Interventions occur after a full medical care, nursing, rehabilitation and social support review have been carried out.. These teams provide medical and nursing care, preventative, curative and rehabilitative actions as well as palliative care, physiotherapy, occupational and psychosocial support and health education. The teams provide support in the Instrumental Activities of Daily ${ }^{[39]}$.

- The Community Support in Palliative Care Teams (ECSCP) provide services in the homes of people who are in a situation of dependency due to terminal illness or convalescence and who cannot move from the home but do not require hospitalization. These teams are the responsibility of primary health care and social support entities (Art. 29. ${ }^{\circ}$ ). They are multidisciplinary teams with specialized training in palliative care, and operate with the support of a doctor and a nurse $\mathrm{e}^{[39]}$.

The interaction and cooperation of professionals from various fields is essential in order to achieve the objective of the UCCI which is the global recovery of the individual through a therapeutic process with social support ${ }^{[33]}$. The intervention must be properly prepared and aim to gain a comprehensive understanding of the user. Therefore it is essential that the training for the care providers is specific and constantly updated, in order for the care to prove effective ${ }^{[40]}$. gressiva. Não existe tempo de permanência pré-definido para estas unidades tendo em conta a complexidade das situações clínicas destes utentes (Art. ${ }^{\circ} 19^{\circ}$ e $20^{\circ}{ }^{[37]}$.

De modo a dar apoio e respostas a situações que necessitam de cuidados continuados mas que não necessitam de internamento, foram criadas unidades específicas que actuam em contexto exterior às UCCI e às unidades hospitalares:

- As Unidades em Ambulatório, designadas Unidades de Dia e de Promoção da Autonomia (UDPA) prestam cuidados integrados de suporte, de promoção de autonomia e de apoio social, em regime ambulatório, a pessoas que, devido à sua situação de dependência, independentemente do nível em que se encontram, não reúnem condições para serem cuidadas no domicílio (Art. ${ }^{\circ}$ 21). Estas unidades prestam cuidados de promoção da autonomia, desenvolvem actividades de manutenção e estimulação, cuidados médicos, de enfermagem, fisiatria, psicossociais, de animação, alimentação e higiene pessoal ${ }^{[38]}$.

- As Unidades de Resposta Domiciliária são constituídas por duas equipas distintas: As Equipas de Cuidados Continuados Integrados (ECCI), constituídas por equipas multidisciplinares, da responsabilidade dos cuidados de saúde primários e das entidades de apoio social que prestam serviços domiciliários a pessoas em situação de dependência funcional, doença terminal ou em processo de convalescença, que não necessitam de internamento mas que não podem deslocar-se do domicílio (Art. ${ }^{\circ} 27^{\circ}$ ). As intervenções decorrem de uma avaliação integral ao nível dos cuidados médicos, de enfermagem, reabilitação e apoio social. Estas equipas asseguram cuidados médicos e de enfermagem de natureza preventiva, curativa e reabilitadora, desenvolvem acções paliativas, cuidados de fisiatria, apoio psicossocial e ocupacional e de educação para a saúde, e apoiam nas Actividades Instrumentais da Vida Diária (AVD) e nas Actividades Instrumentais da Vida Diária (AIVD) ${ }^{[39]}$. Já as Equipas Comunitárias de Suporte em Cuidados Paliativos (ECSCP) prestam serviços no domicílio a pessoas em situação de dependência funcional, doença terminal ou em processo de convalescença que não possam deslocar-se do domicílio, e que a sua situação clinica não requer internamento. Estas equipas são responsabilidade dos cuidados de saúde primários e das entidades de apoio social (Art. ${ }^{\circ} 29^{\circ}$ ). São equipas multidisciplinares, com formação especializada em cuidados paliativos, com um médico e um enfermeiro ${ }^{[39]}$.

De modo a alcançar o objectivo da intervenção das UCCI, que visa a recuperação global do indivíduo, num processo terapêutico e social uno ${ }^{[33]}$, é indispensável a interacção e cooperação de profissionais das várias áreas. Estes devem ser devidamente preparados e vocacionados para uma compreensão global do utente, pelo que é fundamental formação específica e em permanente actualização, de modo a que a intervenção interdisciplinar das equipas multidisciplinares se revele eficaz ${ }^{[40]}$. 


\section{Some of the results of REDE (2008/2013)}

Over its seven years in operation, REDE has significantly expanded in terms of the number of vacancies filed and the opening of new UCCI. This increase has been accompanied by a number of users flagged for entry into the NETWORK. In the third quarterly UMCCI report up to 30/09/2012, 129105 users were referred for admission in various types of units and 97251 had been assisted by that date. Between the year 2011 and the year 2012 there was a significant increase in the number of clients assisted, from 32713 to 39663 which represents an annual increase of $12.1 \%$ $\left(\right.$ UMCCI-2012) ${ }^{[41]}$.

The RNCCI hire hospital beds through service provider agreements between private for-profit orgnisations, IPSS and the National Health Service (NHS). Since the NETWORK began operating on a national level, there has been an increase in the number of agreements covered by the protocols signed between the Ministry of Health, the Ministry of Labour and Social Solidarity and private entities and private non-profit institutions (IPSS) ${ }^{[41]}$. This is reflected in a progressive increase in the number of beds available for new admissions.

\section{Alguns resultados de resposta da REDE (2008 - 2013)}

Ao longo de sete anos de funcionamento da REDE, tem havido um alargamento considerável em termos do número de vagas protocoladas bem como a abertura de novas UCCI. Este aumento tem sido acompanhado pelo aumento do número de utentes sinalizados para ingresso na REDE. O relatório trimestral da UMCCI, relativamente ao terceiro trimestre de 2012, refere que até $30 / 09 / 2012$, foram referenciados para internamento nas diversas tipologias das unidades 129.105 utentes, tendo sido assistidos até essa data 97.251. Entre o ano de 2011 e o ano de 2012, houve um aumento significativo no número de utentes assistidos, passando de 32.713 para 39.663, num aumento anual 12,1\% (UMCCI-2012) ${ }^{[41]}$. No que se refere às respostas de internamento e contratação de camas da RNCCI, estas surgem pela celebração de acordos de prestação de serviços com entidades privadas com fins lucrativos, com IPSS e com o Serviço Nacional de Saúde (SNS). Desde a entrada em funcionamento da REDE, a nível nacional, que têm sido celebrados novos protocolos e outros revistos, o que se tem reflectido num aumento progressivo do número de camas disponíveis para novas admissões.

Desde o início do funcionamento da REDE que o número de acordos tem aumentado, o que revela o aumento significativo do número de camas disponíveis, abrangidas pelos protocolos assinados entre o Ministério da Saúde, o Ministério do Trabalho e da Solidariedade Social e entidades particulares e $\operatorname{IPSS}^{[41]}$..

Table 1 - Evolution of the number of vacancies in Portugal 2008-2012 (CV - convalescence; MDR - medium term and rehabilitation; LDM - Long term and maintenance; $\mathrm{CP}$ - palliative care)

Tabela 1 - Evolução do número de vagas em Portugal Continental de 2008 a 2012 (CV - convalescença; MDR - média duração e reabilitação; LDM - longa duração e manutenção; $\mathrm{CP}$ - cuidados paliativos)

\begin{tabular}{|c|c|c|c|c|c|}
\hline Typology / Tipologia & $\mathbf{1 2 / 2 0 0 8}^{[42]}$ & $\mathbf{1 2}^{2 \mathbf{2 0 0 9}}{ }^{[42]}$ & $\mathbf{1 2 / 2 0 1 0}^{[43]}$ & $\mathbf{1 2 / 2 0 1 1}^{[44]}$ & $\mathbf{1 2 / 2 0 1 2}^{[44]}$ \\
\hline CV & 530 & 625 & 682 & 906 & 867 \\
\hline MDR & 922 & 1253 & 1497 & 1747 & 1820 \\
\hline LDM & 1325 & 1942 & 2286 & 2752 & 3031 \\
\hline CP & 93 & 118 & 160 & 190 & 193 \\
\hline Total & 2870 & 3938 & 4625 & 5595 & 5911 \\
\hline
\end{tabular}


On $31 / 12 / 2009$, there were 3938 contracted internment beds, distributed among different units operating throughout the country. This represented an increase of $37 \%$ compared to $31 / 12 / 2008$ ( 2870 beds) ${ }^{[42]}$. In late 2010 the number rose to 4625 beds, in operation covered by Protocol ${ }^{[43]}$. In the period until 31/12/2011, 970 new beds were included and in 2012 there were only 316 new vacancies ${ }^{[4]}$. One can then verify that during this interval (31/12/2008 to 31/12/2012), 2041 new beds were hired across the country, which corresponds to an average annual growth of around $20 \%$, representing 408 beds in practice terms ${ }^{[44]}$.

In the region of Lisbon and the Tagus Valley, 743 internment beds were contracted in the period until 31/12/2013: 124 were in UCV, 215 in UMDR, 351 in ULDM and 53 in $\mathrm{CP}^{[43]}$. In 2010, the number of contracted beds increased to 891, with 124 beds distributed in CV, 281 in UMDR, 423 in ULDM and 63 in $\mathrm{CP}^{[44]}$. By 31/12/2011, this number increased to 1188 contracted beds in operation 157 of which were in $\mathrm{CV}$ units, 385 in MDR units, 571 in LDM units and 75 in CP units ${ }^{[44]}$. On 31/12/2012 the number of beds in operation had increased to 1267 , corresponding to 157 in $\mathrm{UCV}, 408$ in UMDR, 634 in ULDM and 68 in $\mathrm{CP}^{[44]}$. From $01 / 01 / 2010$ to $30 / 06 / 2012$ there was an actual increase of 536 internment beds ${ }^{[4]}$. However, it has been concluded that new protocols for 44 beds were signed. In short, from the formation of the REDE to the end of 2012, 1323 new beds distributed over the four areas of internment, were contracted in the region of Lisbon and the Tagus Valley. ${ }^{[44]}$.
No final de 2009, o número de camas de internamento contratadas e em funcionamento, em todo o país, era de 3938 camas, distribuídas pelas diversas tipologias, o que representou um aumento de $37 \%$ comparativamente a ao final de 2008 (2870 camas) ${ }^{[42]}$. No final de 2010 , o número subiu para 4.625 camas abrangidas por protocolo e em funcionamento ${ }^{[43]}$. Até final de 2011, verificou-se a inclusão de 970 novas camas de e no ano de 2012 apenas aumentaram 316 novas vagas ${ }^{[44]}$. Pode-se então verificar que neste intervalo de temporal (31/12/2008 e $31 / 12 / 2012$ ), foram contratadas mais 2041 novas camas, em todo o país, o correspondente a um valor médio anual de crescimento na ordem de $20 \%$, o que representa em termos práticos 408 camas $^{[44]}$.

Na região de Lisboa e Vale do Tejo, até final de 2009 foram contratadas 743 camas de internamento, sendo que 124 estavam em UCV, 215 em UMDR, 351 em ULDM e 53 em CP ${ }^{[43]}$. Em 2010, o número de camas contratadas aumentou para 891, estando distribuídas por 124 camas em CV, 281 em UMDR, 423 em ULDM e 63 em CP ${ }^{[44]}$. Até final de 2011, este número aumentou para 1188 camas contratadas e em funcionamento, sendo que 157 eram em unidades de convalescença, 385 em unidades de média duração, 571 em unidades de longa duração e 75 em unidades de cuidados paliativos ${ }^{[44]}$. No final de 2012, o número de camas em funcionamento passou a ser de 1267, correspondendo a $157 \mathrm{em} \mathrm{UCV,} 408 \mathrm{em}$ UMDR, 634 em ULDM e 68 em CP ${ }^{[44]}$. Desde 1/01/2010 até 30/06/2012 verificou-se um aumento efectivo de 536 camas de internamento ${ }^{[44]}$. No entanto, verificou-se que foram celebrados novos acordos, onde foram assinados protocolos para 44 novas camas.

Em suma, desde o início do funcionamento da REDE e até ao final de 2012, na região de Lisboa e Vale do Tejo foram contratualizadas 1323 camas para as quatro tipologias de internamento ${ }^{[44]}$.

Table 2 - Evolution of the number of vacancies in Lisboa e Vale do Tejo 2009-2012 (CV - convalescence; MDR - medium term and rehabilitation;

LDM - Long term and maintenance; $\mathrm{CP}$ - palliative care)

Tabela 2 - Evolução do número de vagas em Lisboa e Vale do Tejo de 2009 a 2012

(CV - convalescença; MDR - média duração e reabilitação;

LDM - longa duração e manutenção; CP - cuidados paliativos) (da ref. 14)

\begin{tabular}{|c|c|c|c|c|c|}
\cline { 2 - 5 } \multicolumn{1}{c|}{} & \multicolumn{3}{c|}{ TYPOLOGIES / TIPOLOGIAS } & \multicolumn{1}{c}{} \\
\hline ANOS & CV & MDR & LDM & CP & TOTAL \\
\hline $\mathbf{2 0 0 9}$ & 124 & 215 & 351 & 53 & 743 \\
\hline $\mathbf{2 0 1 0}$ & 124 & 281 & 423 & 63 & 891 \\
\hline $\mathbf{2 0 1 1}$ & 157 & 385 & 571 & 75 & 1188 \\
\hline $\mathbf{2 0 1 2}$ & 157 & 408 & 634 & 68 & 1323 \\
\hline
\end{tabular}




\section{Conclusions}

It is undeniable that Portugal, like most industrialized countries, is experiencing an irreversible aging process. It is thought that this phenomenon is responsible for the structural and demographic changes of modern society. Economic, social and even cultural factors have contributed to this process which includes aspects of a biological, psychological and social nature. Population aging is the result of human aging associated with increased life expectancy and reduced mortality rate of the young and the middle-aged. The increase in life expectancy is due to scientific progress in health, greater awareness and increased investment at the level of social and health policies, as well as changes in individual behaviors themselves, especially in the adoption of prevention strategies and health promotion. Naturally, the health gains achieved significantly improve survival ability and hence, an increase in life expectancy.

However, the increasing prevalence of chronic and disabling diseases is a direct consequence of human aging and will inevitably result in an increase in demand for solutions not only in terms of health care but also social welfare.

Hospitals were previously the only answer / alternative for people who were in a situation of dependency and who needed special care, even if they did not need the type of care offered in an acute unit. This promoted excessive stays in hospital which had a negative impact economically and on the efficiency and responsiveness to acute situations. In addition, users themselves would be exposed to sources of infection and other adverse elements during recovery. Previously there were clearly no strategies in place to tackle the issue of care provision in acute units and continuing care of patients after their stay in such a unit. Current changes in the structure of society have compelled governing bodies to find new solutions. The commissioning of the REDE in 2006 and the opening of the UCCI aimed to bridge this gap with a comprehensive intervention model that includes health, social and economic aspects and that is composed of multidisciplinary teams.

In the last RNCCI analysis report (3/2013), it was found that the number of referrals for REDE has been gradually increasing and there was an increase of $12 \%$ in the number of clients assisted in the year 2012 alone. These data show how the continuity of the aging process in Portugal demonstrates a growing need for adequate responses to aging and dependency.

The results illustrate the unquestionable importance of REDE and UCCI as an effective and efficient response to the issues of aging and dependency as they

\section{Conclusão}

É inegável que Portugal, tal como a maioria dos países industrializados se encontra num processo de envelhecimento irreversível. Para tal, têm contribuído factores de ordem económica, social e até cultural sendo um processo que assume os vários aspectos, nomeadamente biológicos, psicológicos e sociais. Este envelhecimento populacional resulta do envelhecimento humano associado ao aumento da esperança média de vida e à redução da taxa de mortalidade dos indivíduos jovens e dos de meia-idade. $\mathrm{O}$ aumento da esperança média de vida resulta dos progressos científicos na área da saúde, de uma maior consciencialização e de um maior investimento ao nível das políticas sociais e de saúde, bem como as mudanças nos próprios comportamentos individuais, principalmente na adopção de estratégias de prevenção e promoção da saúde. Naturalmente, os ganhos em saúde alcançados proporcionam o aumento significativo da capacidade de sobrevivência e, consequentemente, o aumento da esperança média de vida. Uma das consequências directas do envelhecimento humano é o aumento da prevalência de doenças crónicas e incapacitantes que, inevitavelmente resultam em aumento das necessidades e da procura de respostas não só na área da saúde como também ao nível social.

Até 2006, as unidades hospitalares constituíam a única resposta/alternativa para as pessoas que se encontravam em situação de dependência e com necessidade de cuidados diferenciados, mesmo que estas não necessitassem de cuidados típicos de uma unidade de agudos. Estas ocorrências promoviam permanências excessivas nas unidades hospitalares, causando um impacto negativo não só ao nível da eficiência e capacidade de resposta a situações agudas, como em termos económicos, e para os próprios utilizadores uma vez que permaneciam expostos a focos de infecção e outros elementos adversos à sua recuperação. Sem dúvida que não existiam respostas de ligação entre a prestação de cuidados em situação aguda e a continuação de cuidados sem necessidade de internamento específico em unidades de aguados.

Pelas mudanças na estrutura da sociedade as entidades governantes foram compelidas a encontrarem novas soluções. A entrada em funcionamento da REDE em 2006 e a abertura das UCCI vieram colmatar esse vazio existente, com a efectivação de um modelo de intervenção abrangente que comtempla as vertentes da saúde, social e económica dos utentes, e composto por equipas multidisciplinares.

Em análise ao último relatório da $\mathrm{RNCCI}^{[44]}$ verificou-se que o número de referenciações para a REDE tem 
take health, social and economic aspects into account. UCCI professionals should be specialized in order to respond to the changes in the morphology of the elderly and / or increasingly dependent persons. Nevertheless, this is still a relatively recent initiative in Portugal. The numbers of carers trained in the CCI is still small so it is of utmost importance to focus on the training and specialization of these multidisciplinary teams so that the objectives of REDE can be fully achieved.

\section{Conflict of Interests}

The authors declare that they have no financial or personal relationships that could be construed as having potential conflicts of interest. vindo a aumentar gradualmente bem como o número de utentes assistidos pelo que, só no ano de 2012 houve um aumento de $12 \%$. Estes dados revelam a continuidade do processo de envelhecimento em que Portugal se encontra, perspectivando-se uma crescente necessidade de respostas adequadas ao envelhecimento e à dependência.

Perante estes resultados, é indiscutível a importância da REDE e das UCCI como uma resposta efectiva e eficaz no âmbito da velhice e da dependência, tendo em conta que o seu campo de actuação, na área da saúde, sem descurar a vertente social e económica, elementos fundamentais para uma intervenção total.

Nesse sentido, e tendo em conta as alterações na morfologia da população idosa e/ou dependente, cada vez mais a intervenção dos profissionais das UCCI deve ser especializada. Não obstante deste ser ainda um processo relativamente recente em Portugal, a formação na área dos CCI é ainda diminuta pelo que se reveste de maior importância a aposta na formação e especialização destas equipas multiprofissionais para que o objectivo da REDE seja alcançado de forma integral.

\section{Conflito de interesses}

Os autores declaram que não existem quaisquer relações pessoais ou financeiras que possam ser consideradas como um potencial conflito de interesses 


\section{References / Referências}

[1] Paschoal SMP. In: Qualidade de Vida do Idoso: Elaboração de um instrumento que privilegia sua opinião [dissertação]. São Paulo: Faculdade de Medicina, Universidade de São Paulo; 2000.

[2] Sequeira, C. Cuidar de idosos com dependência física e mental. Lisboa: Lidel;2010.

[3] Robertis, C. Fundamentos del trabajo social. Valência: Nau Llibres;2003.

[4] Osório, AR. Os idosos na sociedade actual. In Osório AR \& Pinto, FC. (Eds). As pessoas idosas - contexto social e intervenção educativa. Lisboa: Instituto Piaget; 2007.p.11-46.

[5] Figueiredo, D. Cuidados familiares ao idoso dependente. Lisboa, Climepsi Editores; 2007.

[6] Ferreira, PL. et al. Tradução e validação para a língua portuguesa do questionário de planeamento da alta (PREPARED). Rev. Enf. Ref. [online]. 2011, vol.serIII, n.5, pp. 121-133. ISSN 0874-0283. Acedido em 12 Setembro 2013. In URL: http://dx.doi.org/10.12707/ RIII1032.

[7] Gonçalves, C. e Carrilho, MJ. Envelhecimento crescente mas espacialmente desigual. Revista Estudos Demográficos, $\mathrm{n}^{\circ} 40$. INE, Ed 2006, p.21-37.

[8] Squire, A. Saúde e bem-estar para pessoas idosas- Fundamentos básicos para a prática. Loures: Lusociência; 2005.

[9] Fontaine, R. Psicologia do envelhecimento. Lisboa: Climepsi Editores; 2000. ISBN $972-$ 8449-65-8.

[10] Ferreira, PL., Rodrigues, R. \& Nogueira, D. Avaliação multidimensional em idosos. Coimbra: Mar da Palavra, Edições, Lda; 2006

[11] Stuart-Hamilton, I. A Psicologia do desenvolvimento: uma introdução. Porto Alegre RS: Artmed Editora; 2008.

[12] Vaz, ME. O quotidiano do idoso - esperança ou desesperanças. Rev. Intervenção Social, Julho/ 2001. Lisboa, ISSS - Departamento Editorial; 2001.

[13] Giddens, A. Sociologia. Lisboa: Fundação Calouste Gulbenkian; 2000

[14] CID - Grupo de Coordenação do Plano de Auditoria Social. Manual de Boas Práticas, Um guia para o acolhimento residencial das pessoas em situação de deficiência - para dirigentes, profissionais, residentes e familiares. Lisboa: Instituto da Segurança Social, I.P., s/d. ISBN972-99152-7-X.

[15] Fernandes, AA. Velhice, solidariedades familiares e política social: itinerário de pesquisa em torno do aumento da esperança de vida. Rev. Sociologia, $n^{\circ} .36$, p.39-52. ISSN08736529, Setembro 2001

[16] Barreto, A. A Situação Social em Portugal, 1960-1999. Vol II. Lisboa: Instituto de Ciências Sociais da Universidade de Lisboa; [online] 2002. Acedido em 12 Setembro 2013. In URL: http://www.ics.ul.pt/publicacoes/ workingpapers/wp2002/WP6-2002.pdf

[17] Dias, A. \& Santana, S. Cuidados integrados - Um novo paradigma na prestação de cuidados de saúde. (Out/Dez 2008-Jan/Mar 2009). Rev. Portuguesa e Brasileira de Gestão; 2009; p.12-20.
[18] UMCCI- Relatório de monitorização do desenvolvimento e da actividade da Rede Nacional de Cuidados Continuados Integrados (RNCCI) - $1^{\circ}$ Semestre de 2012 [online]. Julho 2012. Acedido em 8 Setembro 2013. In URL: http://www.rncci.min-saude.pt/SiteCollectionDocuments/rev relatorio 1 semestre_2012.pdf.

[19] Carrilho, MJ \& Gonçalves, C. Dinâmicas territoriais do envelhecimento: análise exploratória dos resultados dos Censos 91 e 2001. Revista de Estudos Demográficos n ${ }^{\circ} 36$. INE, Ed.. 2004; p.175-191.

[20] Carrilho, MJ. \& Patrício, L. A Situação demográfica recente em Portugal. Revista Estudos Demográficos nº40. INE, Ed. 2007; p.39-75.

[21] Gonçalves,C. \& Carrilho, MJ. Envelhecimento crescente mas espacialmente desigual. Revista Estudos Demográficos, $n^{\circ} 38$. INE, Ed. 2006; pp. 111-140.

[22] INE. Projecções de população residente em Portugal 2008-2060. [online]. Março 2009. Acedido em 21 Agosto 2013. In URL: http://www. ine.pt $/ x p o r t a l / x$ main? $x p i d=I N E \& x p g i d=i n e$ publicacoes\&PUBLICACOESpub_boui $=65 \overline{9}$ 44632\&PUBLICACOESmodo $=2 \&$ xlang $=p t$

[23] INE. Censos 2011. Lisboa (INE, Ed.) [online]. 2012 Acedido em 8 Setembro 2013. In URL: http://censos.ine.pt/xportal/xmain?xp $\mathrm{id}=$ CENSOS\& $\mathrm{xpgid}=$ censos2011_apresentacao.

[24] Campos, L., Saturno P. \& Carneiro, A. Plano Nacional de Saúde 2011-2016- A qualidade dos cuidados e dos serviços. PNS 2011-2016 [online]. 2010. Acedido em 8 Setembro 2013. In URL: http://pns.dgs.pt/files/2010/07/ Q2.pdf.

[25] Lopes, ML. Plano Nacional de Saúde 20112016 - Cuidados Continuados Integrado em Portugal - analisando o presente, prespectivando o futuro. PNS 2011-2016 [online]. 2010. Acedido em 8 Setembro 2013. In URL: http://pns.dgs.pt/files/2010/08/CSC1.pdf.

[26] Carreira, HM. As Políticas Sociais em Portugal. Lisboa: Gradiva; 1996.

[27] MTSS. A dependência: o apoio informal, a rede de serviços e equipamentos e os cuidados continuados integrados Carta Social: Rede de serviços e equipamentos. Lisboa: Gabinete de Estratégia e Planeamento (GEP); 2009.

[28] Carvalho, MILB. Envelhecimento e cuidados domiciliários em instituições de solidariedade social. Lisboa: Coisas e Ler; 2012.

[29] Fernandes, E. Por uma carta ética da Intervenção Social. Rev. Intervenção Social, Julho/2004. Lisboa, ISSS - Departamento Editorial; 2004.

[30] Correia, JM. Introdução à Gerontologia. Lisboa: Universidade Aberta; 2003.

[31] Decreto-Lei n. ${ }^{\circ} 101 / 2006$. Diário da República - I SÉRIE-A, de 6 Junho 2006, [online]. 2006. Acedido em 8 Setembro 2013. In URL: http://dre.pt/pdf1sdip/2006/06/10 9A00/38563865.pdf.

[32] Netto, MP. \& Ponte, JR. Envelhecimento: desafio na transição do século. In: Papaléo Netto, M. (Coord.) Gerontologia: a velhice e o envelhecimento em visão globalizada. São Paulo: Atheneu; 2002. p.3-12.
[33] RNCCI.A nossa Missão. [online]. 2006. Acedido em 8 Setembro 2013. In URL: http:/ www.rncci.min-saude.pt/umcci/Paginas/ ANossaMissao.aspx.

[34] RNCCI. Unidades de Convalescença. [online]. 2010. Acedido em 8 Setembro 2013. In URL: http://www.rncci.min-saude.pt/rncci/ constituicao/internamento/Paginas/UnidadesdeConvalescenca.aspx

[35] RNCCI. Unidades de Média Duração e Reabilitação. [online]. 2010. Acedido em 8 Setembro 2013. In URL: http://www.rncci. min-saude.pt/rncci/constituicao/internamento/Paginas/UnidadesdeMediaDuracaoeReabilitacao.aspx

[36] RNCCI. Unidades de Longa Duração Reabilitação. [online]. 2010. Acedido em 8 Setembro 2013. In URL: http://www.rncci. min-saude.pt/rncci/constituicao/internamento/Paginas/UnidadesdeLongaDuracaoeManutencao.aspx

[37] RNCCI. Unidades de Cuidados Paliativos. [online]. 2010. Acedido em 8 Setembro 2013. In URL: http://www.rncci.min-saude. $\mathrm{pt} / \mathrm{rncci} /$ constituicao/internamento/Paginas/ UnidadesdeCuidadosPaliativos.aspx

[38] RNCCI. Unidades de Dia e Promoção da Autonomia. [online]. 2006. Acedido em 8 Setembro 2013. In URL: http://dre.pt/pdf1 sdip/2006/06/109A00/38563865.pdf http:// www.rncci.min-saude.pt/rncci/constituicao/ Paginas/Ambulatorio.aspx

[39] RNCCI. Respostas Domiciliárias. [online]. 2010. Acedido em 8 Setembro 2013. In URL: http://www.rncci.min-saude.pt/rncci/constituicao/Paginas/RespostasDomiciliarias.aspx

[40] Saúde, DG. Manual de Boas Práticas para os Assistentes Sociais da Saúde na Rede Nacional de Cuidados Continuados Integrados, Circular normativa $\mathrm{N}^{\circ}$ : 29/DSPCS. de 07/07/06. [online]. 2010. Acedido em 8 Setembro 2013. In URL: http://www.dgs.pt/ upload/membro.id/ficheiros/i008206.pdf

[41] RNCCI. Ponto de situação da RNCCI: trimestral - Setembro 2012.[online]. 2010. Acedido em 8 Setembro 2013. In URL: http://www. umcci.min-saude.pt/Paginas/Default.aspx

[42] UMCCI. Relatório de monitorização do desenvolvimento e da actividade da Rede Nacional de Cuidados Continuados Integrados 2009. Fev.2010 [online]. 2010. Acedido em 8 Setembro 2013. In URL: http://www.rncci.min-saude.pt/SiteCollectionDocuments/Relatorio Anual RNCCI_2009FINAL29032010A.pdf

[43] UMCCI. Relatório de monitorização do desenvolvimento e da actividade da Rede Nacional de Cuidados Continuados Integrados 2010. Mar.2011.[online]. 2011. Acedido em 8 Setembro 2013. In URL: http://www.rncci.min-saude.pt/SiteCollectionDocuments/ RelatorioAnualRNCCI2010VersaoFinal.pdf

[44] RNCCI. Implementação e Monitorização da Rede Nacional de Cuidados Continuados Integrados-Relatório Final. Mar.2013. [online]. 2013. Acedido em 10 Setembro 2013. In URL: http://www4.seg-social.pt/ documents/10152/3735071/Rel_Imple_Monit_RNCCI 2013 